\title{
Human-Centric Regulatory in Point-of-Care Manufacturing for 3D Printed PEEK Polymer Implants with Functionalized Implant Surface
}

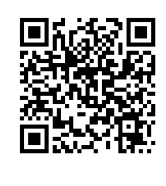

Dietmar Schaffarczyk $k^{1,3,6 *}$, Christoph Koslowski², Jennifer Knaus ${ }^{3}$, Sebastian Spintzyk ${ }^{4}$, Andreas Schwitalla ${ }^{5}$
and Sonia Seubert

${ }^{1}$ ETH Zürich, Switzerland

${ }^{2} A G$ PolyMORE; Switzerland

${ }^{3}$ Stimos GmbH, Germany

${ }^{4}$ University of Tübingen, Germany

${ }^{5}$ Charité University Medicine Berlin, Germany

${ }^{6} Q S$ Schaffhausen $A G$, Switzerland

${ }^{7}$ Mazars Rechtsanwaltsgesellschaft Berlin, Germany

Submission: September 29, 2021; Published: October 08, 2021

*Corresponding author: Dietmar Schaffarczyk, Stimos GmbH, Germany

\section{Abstract}

This article aims to define a regulatory approach for future medical technologies to be applied to the research, design, development, and manufacturing of smart medical devices. In the scope of this perspective: A human-centric regulatory approach and regulatory thinking method for 3D printed PEEK polymer implants.

Keywords: POC solution; polymer; smart implant; regulatory thinking; human-centric regulatory; S.P.E.L.; surface functionalization; additive manufacturing

\section{Introduction}

The healthcare industry is in a transformative change: one of the key enablers of these changes is the proliferation of pointof-care (POC) technologies, which can improve clinical outcomes and reduce costs by increased access. POC technologies have the potential to improve the management and treatment of various diseases and conditions, especially in resource-limited settings, where healthcare infrastructure is weak and access to quality and timely care is challenging. POC technologies are gaining ground in four areas in particular: (1) IVD, (2) SaMD, (3) surgery, specifically in orthopedics, CMF, and dental surgery, (4) preparation of surgery. While POC solutions in the diagnostic or SaMD (software as medical device) area make the products available to the patient $24 / 7$, mostly in their home environment, POC technologies in the orthopedic-surgical area bring the products directly to the user in the outpatient clinic or hospital. This paradigm shift in healthcare delivery is vastly enabled due to the advancements in material processing methods and the easy accessibility of soft- and hardware technologies. Many techniques are used to process materials to be used in medical applications. Traditional manufacturing process methods include injection and compression molding, extrusion, milling or machining. Additionally, advancements in additive manufacturing (AM) continue to provide new opportunities for biomedical applications by creating more complex architectures. It allowed for the fabrication of custom implants with microscale resolution. Although the efficiency of the process is unclear, AM is a potential process for manufacturing implants to be used in different applications. It can be stated that AM is a technology that may solve many problems in diverse fields. However, in all application areas, further studies are needed to improve the manufacturing of custom-made implants because no standard methodology is currently available. Furthermore, the advantages and disadvantages of the process are not yet clearly defined [1]. Besides the selective laser sintering (SLS) technique, fused 
deposition modeling (FDM) is currently the most widely used strategy for 3D printing, providing a low-cost technology for processing metals or thermoplastic materials [2-3]. In the FDM / FFF (fused filament fabrication) process, a filament is extruded from a nozzle continuously while heated to a semiliquid state, then the filament rapidly adheres with the surrounding material and solidifies, and the deposits follow a certain routine to form the desired shape [4]. Analyzing different AM technologies to produce polymeric implants, it can be stated that FFF is a rapidly growing field (Table 1).

Table 1: Abbreviations, terms and definitions.

\begin{tabular}{|c|c|c|}
\hline Abbreviation & Term & Definition/Explanation \\
\hline 3DPT & 3D Printing Technology & Additive manufacturing method. \\
\hline $\mathrm{AM}$ & Additive Manufacturing & 3D printing technology \\
\hline FDM & Fused Deposition Modelling & Filament based AM \\
\hline FFF & Fused Filament Fabrication & Material to be used for FDM \\
\hline IVD & In-vitro Diagnostic & Device used in diagnoses of diseases \\
\hline MDR & $\begin{array}{l}\text { Medical Device Regulation (Regulation EU } \\
\text { 2017/745) }\end{array}$ & $\begin{array}{l}\text { Legal (EU) framework for design and development, manufactur- } \\
\text { ing, marketing, and observation of medical devices. }\end{array}$ \\
\hline POC & Point of Care & Manufacturing and delivery method \\
\hline RCT & Randomized Controlled Trial & $\begin{array}{l}\text { Golden standard setting for clinical trials to proof safety, clinical } \\
\text { performance, and clinical benefit. }\end{array}$ \\
\hline S.P.E.L. & Safety and Performance Evidence Level & $\begin{array}{l}\text { Method based on Regulatory requirements to proof safety and } \\
\text { pre-clinical performance of implant finishing technologies or } \\
\text { latest manufacturing methods. }\end{array}$ \\
\hline SaMD & Software as Medical Device & $\begin{array}{l}\text { Often used as a therapeutic or rehabilitation device in a home- } \\
\text { care setting }\end{array}$ \\
\hline SFT & Surface Functionalization Technology & $\begin{array}{l}\text { Surface modification technology to achieve enhance osseointe- } \\
\text { grative material characteristics. }\end{array}$ \\
\hline SIM & Standard Implantable Material & Polymers (PEEK, PPSU), Metals (Titanium) or Ceramics \\
\hline SLS & Selective Laser Sintering & Powder based AM technology \\
\hline SSCP & Summary of Safety and Clinical Performance & Regulatory requirement \\
\hline TRH & Thermal Radiation Heating & Working principle / mode of operations in 3D printing processes \\
\hline
\end{tabular}

Over the past few years, the high-performance polymer Polyetheretherketone (PEEK) has become increasingly popular in medical applications due to its good mechanical characteristics, rendering it an excellent alternative to metallic biomaterials for load-bearing applications. PEEK devices with sophisticated shapes and controlled architecture can be currently produced using 3D printing. However, the mechanical properties and biocompatibility of FFF-printed PEEK and its composites are still not clear [5]. To analyze the safety and performance and clinical benefit of available POC products and to define a possible setting of POC solutions, the authors want to take a closer look at the technological readiness of the increasing field of 3D printing processes and 3D printed PEEK implants and performed a detailed scientific literature search and review, focusing on the areas of orthopedics, CMF, and dental surgery. In this context, an evaluation focus will be the legal and regulatory and/or certification requirements of AM implants or the AM technology in general. Furthermore, a case study of a setup for 3D printed PEEK polymer implants with a functionalized implant surfaces will be briefly introduced.

\section{Literature Evaluation}

High-evidence studies evaluating manufacturing methods as well as general safety and performance requirements of the product have been in scope for the literature identification; as such, a focus was put on (systematic) review articles and metaanalyses. For this literature search, PubMed (MEDLINE) was chosen as the main data source because:

i. PubMed comprises over 26 million citations for biomedical literature from MEDLINE, life science journals, and online books. PubMed citations and abstracts include the fields of biomedicine and health, covering portions of the life sciences, behavioral sciences, chemical sciences, and bioengineering.

ii. The majority of journals selected for MEDLINE are based on the recommendation of the Literature Selection Technical Review Committee (LSTRC), an NIH-chartered advisory committee of external experts analogous to the committees that review NIH grant applications (Table 2).

No RCT's nor clinical trials in a comparative setting could be found. Only few studies describe the use of 3D printed PEEK implants in clinical use. Including pre-clinical, mechanical and/or experimental settings the use of 3D printed PEEK implants can be divided into the following subgroups of applications (Table 3): 
Academic Journal of Polymer science

Table 2: Literature search details.

\begin{tabular}{|c|c|c|}
\hline Database searched & Medline / PubMed \\
\hline Keywords \& Search Terms & "3D printed PEEK" \\
\hline Keywords \& Search Terms & (3D AND printed) AND (PEEK AND implant) \\
\hline
\end{tabular}

Table 3: Applications related to PEEK AM (lit. search 2021-05-19).

\begin{tabular}{|c|c|c|c|c|c|c|}
\hline Application & CMF & dental & spinal & orthopedic & others & Medical application \\
\hline Number of hits & 21 & 11 & 10 & 8 & 7 & 18 \\
\hline
\end{tabular}

\section{Results}

\section{Preclinical safety and performance data}

As the majority of the studies found in the literature search describe preclinical results often in a very experimental setup, it became clear that there is still no sound methodology published or made available from the suppliers of AM equipment that would facilitate the manufacturing process of the polymer implants to be used in a clinical POC setting and its reliability. Although recent advances in additive manufacturing technology now enable FFF of implantable grade Polyetheretherketone (PEEK), a lot of additional, critical parameters must be first analyzed and respected during the manufacturing process of PEEK-AM implants: This includes but is not limited to the printing speed of the print head nozzle, nozzle-diameter, print-chamber temperature and the printing direction: Alle these parameters have a critical effect on safety and (clinical) performance of the AM implant and may result in different mechanical characteristics compared to traditional manufactured PEEK implants. The crystallinity of printed PEEK did not differ significantly from as-machined PEEK geometries from extruded rods, indicating that the processing provides a similar microstructure [6]. Most publications conclude that PEEK is a prime candidate to replace, for example, metallic implants and prostheses in orthopedic, spine, and cranio-maxillofacial surgeries. FFF seems to be an economical and efficient threedimensional (3D) printing method to fabricate PEEK implants. However, studies pertaining to the bioactivity of FFF 3D printed PEEK are still lacking [7]. Analyzing the material characteristics of PEEK filaments, it can be assumed that AM PEEK implants may suffer from the same bioinert characteristics as machined or injection-molded PEEK implants. Remarkably, none of the publications discussed regulatory or certification requirements of AM implants or the AM technology in general. No publication gave a review or an opinion of the legal and regulatory prerequisites and consequences to the technological readiness of $\mathrm{AM}$ solutions to be used in a POC setting. To close this gap, the authors will shortly introduce the reader to the legal and regulatory background for POC solutions.

\section{Regulatory requirements}

Although point-of-care solutions, and especially the ideas of implants individually adapted to the needs of patients and even printed organs [7-8], inspire the imagination of visionaries, it must be stated for the moment that truly "smart" implants still seem to be visionary dreams of the future. However, it is important to have these visions in mind: This is the only way to free implant manufacturing from traditional process constraints. Often, production, working principles, and applications of implants are based on milling and molding as the traditional manufacturing method of choice. However, medical technology often seems cumbersome because the medical devices must undergo established and fixed procedures for verification, validation, and approval combined with legal restrictions and insurance issues [9]. Since medical technology products are used at or in the patient, it is imperative to always keep these products' safety and (clinical) performance in mind. Manufacturers must do everything possible to eliminate or minimize risks to the patient. Manufacturers shall - among others - establish, implement, document, and maintain a risk management system [10]. Risk management shall be understood as a continuous iterative process throughout the entire lifecycle of a device, requiring regular, systematic updating. Risk control measures adopted by manufacturers for the design and manufacture of the devices shall conform to safety principles, taking account of the generally acknowledged state of the art. To reduce risks, manufacturers shall manage risks so that the residual risk associated with each hazard and the overall residual risk is judged acceptable. In selecting the most appropriate solutions, manufacturers shall eliminate or reduce risks as far as possible through safe design and manufacture [11].

In addition, the legislator requires from the manufacturer that the devices shall be designed and manufactured in such a way as to ensure that the characteristics and performance requirements referred to in Chapter I of Annex I of Medical Device Regulation (Regulation EU 2017/745) are fulfilled. Particular attention shall be paid to the impact of the different processes on material properties, the mechanical properties of the materials used, and surface properties, reflecting, where appropriate, matters such as strength, ductility, fracture resistance, wear-resistance and fatigue resistance [12]. Unfortunately, regulations and legal texts such as standards and norms and/or the Medical Device Regulation (Regulation EU 2017/745) are not written to anticipate safety and (clinical) performance requirements for future technologies but attempt to describe what is already established in a set of regulations. Innovative technologies and POCs are therefore not found in these texts and fall outside the scope. To ensure that innovative technologies can still be used in the treatment of patients, it is particularly most important to know precisely the applicable standards and laws. This is the only way to ensure that 
the intent of the underlying regulation is adhered to, even in the case of new, innovative, and promising technologies, and that the requirements of the regulations and laws are also adapted and applied in their "original sense" to new technologies and methods.

The lowest common but most important denominator must be found here and can be described as follows: to always ensure the safety and (clinical) performance of medical technology utilizing a transparent and risk-based approach [13]. Visionary solutions drive research and development. However, to implement the results of experimental research as a medical device, it is advisable for the technology drivers to drive "on sight". This means that all responsible economic actors regarding POCs must take all necessary steps to ensure the safety and (clinical) performance of the product at or in the patient. Even though custom-made POCs do not have to follow the regular path of product certification and the use of a product specifically tailored to an individual patient may not require the approval of a Notified Body or other regulatory authorities, the approval of the Ethics Committee must still be obtained before use. The use of not established products and/or procedures on patients always has an inherent exploratory purpose. The decision-makers here also need to be assured that the product is as safe and powerful as possible. Thus, it is recommended to evaluate the safety and (clinical) performance characteristics of POC products to the safety and (clinical) performance characteristics of more traditional or conventional products. In order authorities can proof the decision, this evaluation shall be performed as SSCP (Summary of safety and Clinical Performance) report, as suggested by Medical Device Regulation (Regulation EU 2017/745).

Thus, it is often essential to adjust overly ambitious plans somewhat and evaluate the POC product against the state of the art. State of the art is defined as what is implied: a specific technical capability related to processes, products, and services, based on the findings of science, technology, and experience. State of the art can be defined as "developed stage of technical capability at a given time regarding products, processes, and services, based on the relevant consolidated findings of science, technology, and experience" [14]. This state of the art cannot be compared with the state of science. Instead, it is more in line with generally accepted technical and medical "good practices", whereas the state of science takes research into account and may also be experimental only.

\section{Regulatory Thinking in an Human-Centric Regulatoiry Approach}

The vision of the authors and the goal of the joint efforts can be described with the following statement: "For the benefit of the patient, we pursue the transfer of pioneering, medical technology concepts into industrial application. The aim is to comply with all regulatory requirements or to "redefine" them in the sense of MDR (EU) 2017/745 and all applicable laws." A methodological thinking approach called "Human Centric Regulatory" (HCR), defined by RegulatoryExperts@ETHzürich shall be applied to the research and development efforts of academia and industry to ensure that the most promising research results can be translated into industrial applications. HCR is a regulatory strategy in the sense of "Regulatory Thinking" (RT) that considers the interests of the various stakeholders in medical technology. Stakeholders identified are patients, physicians and healthcare professionals, operators of medical centers and hospitals, insurance companies and health insurers, certification authorities and notified bodies. In addition to efforts in research, design, and development, it is important for the members of the consortium to consider the various needs of the different stakeholders: safety, performance, and efficacy of the products, verification and validation of the technologies, transparency in documentation, proof of positive healthcare effect, as well as compliance with regulatory requirements (MDR (EU) 2017/745) and legal requirements such as, e.g., the MPBetreibV (Medical Devices Operator Ordinance) in Germany. During product or technology development the group will follow the S.P.E.L. (Safety and Performance Evidence Level) requirements.

\section{S.P.E.L. - Safety and Performance Evidence Level}

Here, we want to introduce a setup of point-of-care manufacturing of 3D printed polymer implants with functionalized surfaces. The authors strongly suggest differentiating various working principles and classifying them according to a risk-based approach inspired by Regulation (EU) 2017/745, Annex 8 (Table 4). As 3D printed parts manufactured in the medical and medtech environment are intended to be used as (patient-matched) implants or (patient-specific) instruments, the authors developed a catalog of safety and performance requirements mandatory for 3D printing technologies and inspired by Regulation (EU) 2017/745, Annex 1 (Table 5).

Table 4: Risk Classification for 3D printing technologies.

\begin{tabular}{|c|c|c|}
\hline \multicolumn{3}{|r|}{ Risk Classification 3D Printing Technologies } \\
\hline Class 1 & low risk & 3D printing technology using consistently one medical grade material, pure of sort. \\
\hline Class 2a & medium risk & $\begin{array}{l}\text { 3D printing technology combining different medical grade materials / SIMs resulting in a composite product or } \\
\text { hybrid product. }\end{array}$ \\
\hline Class 2b & medium risk & $\begin{array}{l}\text { 3D printing technology combining different medical grade materials / SIMs including bio-chemical materials such as } \\
\text { HA, tissue, etc. resulting in a composite product or hybrid product. }\end{array}$ \\
\hline Class 3 & high risk & 3D printing technology combining different SIMs including pharmaceuticals to enable drug delivery or deposition. \\
\hline
\end{tabular}


Table 5: Essential safety and performance requirements for 3D printing technologies.

\begin{tabular}{|c|c|c|}
\hline Clause & $\begin{array}{l}\text { Related MDR } \\
\text { Clause }\end{array}$ & Description \\
\hline 1 & & $\begin{array}{l}\text { 3DPTs shall be planned and developed in a structured and documented way. All design and development steps } \\
\text { must be reviewed, evaluated, and approved. }\end{array}$ \\
\hline $1 \mathrm{a}$ & & $\begin{array}{l}\text { Crucial design and development steps must be approved in a risk-based approach. Main design and develop- } \\
\text { ment must be verified. }\end{array}$ \\
\hline $1 \mathrm{~b}$ & & 3DPT must be validated. \\
\hline 2 & \multirow{3}{*}{ SPR 1} & $\begin{array}{l}\text { 3D printing technologies (3DPTs) shall achieve the performance intended by their manufacturer and shall be } \\
\text { designed and manufactured in such a way that, during normal conditions of use, they are suitable for their } \\
\text { intended purpose. They shall be safe and effective and shall not compromise the clinical condition or the safety } \\
\text { of patients or users' safety and health. }\end{array}$ \\
\hline $2 \mathrm{a}$ & & 3DPT for enhanced osseointegration shall allow for early bone formation and an adherent and dense cell layer. \\
\hline $2 \mathrm{~b}$ & & $\begin{array}{c}\text { 3DPT for enhanced osseointegration shall allow for high BIC with a balanced ratio of old "parent" bone and new } \\
\text { bone. }\end{array}$ \\
\hline 3 & \multirow{6}{*}{ SPR 10.1} & $\begin{array}{l}\text { 3DPTs shall be designed and manufactured in such a way as to ensure that the characteristics and performance } \\
\text { requirements referred to in MDR, Annex 1, Chapter I are fulfilled. Particular attention shall be paid to: }\end{array}$ \\
\hline $3 \mathrm{a}$ & & $\begin{array}{c}\text { the choice of materials and substances used, particularly as regards toxicity and biocompatibility, metabolic } \\
\text { reactivity; }\end{array}$ \\
\hline $3 \mathrm{~b}$ & & $\begin{array}{l}\text { the compatibility between the materials and substances used and biological tissues, cells, and body fluids, taking } \\
\text { account of the intended purpose of the 3DPT and, where relevant, absorption, distribution, metabolism, and } \\
\text { excretion; }\end{array}$ \\
\hline $3 c$ & & $\begin{array}{l}\text { the mechanical properties of the 3DPT on the implant, reflecting, where appropriate, wear-resistance and abra- } \\
\text { sion; }\end{array}$ \\
\hline $3 \mathrm{~d}$ & & surface properties such as homogeneity and (layer) thickness \\
\hline $3 \mathrm{e}$ & & the confirmation that the 3DPT meets any defined chemical and/or biological specifications. \\
\hline 4 & \multirow[t]{2}{*}{ SPR 10.2} & $\begin{array}{l}\text { 3DPT modified devices shall be designed, manufactured, and packaged in such a way as to minimize the risk } \\
\text { posed by contaminants and residues to patients, taking account of the intended purpose of the device, and to the } \\
\text { persons involved in the transport, storage, and use of the devices. It must be taken into account that packaging } \\
\text { materials may react with 3DPT. }\end{array}$ \\
\hline $4 \mathrm{a}$ & & Confirmation that packaging material does not interact with or react to 3DPT. \\
\hline 5 & SPR 10.4.1 & $\begin{array}{l}\text { 3DPTs shall be designed and manufactured in such a way as to reduce as far as possible the risks posed by } \\
\text { substances or particles, including wear debris, degradation (products), and processing residues that may be } \\
\text { released from the 3DPT. }\end{array}$ \\
\hline 6 & SPR 10.6: & $\begin{array}{l}\text { 3DPTs shall be designed and manufactured in such a way as to reduce as far as possible the risks linked to the } \\
\text { size and the properties of particles, which are or can be released into the patient's or user's body unless they } \\
\text { come into contact with intact skin only. Special attention shall be given to nanomaterials. }\end{array}$ \\
\hline
\end{tabular}




\begin{tabular}{|c|c|c|}
\hline 7 & \multirow{4}{*}{11.1} & $\begin{array}{l}\text { 3DPTs and their manufacturing processes shall be designed in such a way as to eliminate or to reduce as far as } \\
\text { possible the risk of infection to patients, users and, where applicable, other persons. The design shall: }\end{array}$ \\
\hline $7 a$ & & allow easy and safe handling, \\
\hline $7 \mathrm{~b}$ & & as far as possible, avoid any microbial leakage from the device and/or microbial exposure during use, and \\
\hline $7 \mathrm{c}$ & & prevent microbial contamination of the device or its content such as specimens or fluids. \\
\hline 8 & 11.2 & 3DPTs shall be designed to allow for safe cleaning, disinfection, and/or sterilization. \\
\hline 9 & SPR 12.2 & $\begin{array}{l}\text { Devices that are composed of substances or of combinations of substances that are intended to be introduced } \\
\text { into the human body, and that are absorbed by or locally dispersed in the human body shall comply with the } \\
\text { relevant requirements laid down in Annex I to Directive 2001/83/EC for the evaluation of absorption, distribu- } \\
\text { tion, metabolism, excretion, local tolerance, toxicity, interaction with other devices, medicinal products or other } \\
\text { substances and potential for adverse reactions, as required by the applicable conformity assessment procedure } \\
\text { under this regulation. }\end{array}$ \\
\hline 10 & \multirow{4}{*}{ SPR 13.2} & $\begin{array}{l}\text { For 3DPTs manufactured utilizing tissues or cells of animal origin, or their derivatives, which are non-viable or } \\
\text { rendered non-viable the following shall apply: }\end{array}$ \\
\hline $10 \mathrm{a}$ & & $\begin{array}{l}\text { where feasible taking into account the animal species, tissues, and cells of animal origin, or their derivatives, } \\
\text { shall originate from animals that have been subjected to veterinary controls that are adapted to the intended use } \\
\text { of the tissues. Information on the geographical origin of the animals shall be retained by manufacturers; }\end{array}$ \\
\hline $10 \mathrm{~b}$ & & $\begin{array}{l}\text { sourcing, processing, preservation, testing, and handling of tissues, cells, and substances of animal origin, or } \\
\text { their derivatives, shall be carried out in a way as to provide safety for patients, users and, where applicable, } \\
\text { other persons. In particular, safety with regard to viruses and other transmissible agents shall be addressed by } \\
\text { implementation of validated methods of elimination or viral inactivation in the course of the manufacturing pro- } \\
\text { cess, except when the use of such methods would lead to unacceptable degradation compromising the clinical } \\
\text { benefit of the device; }\end{array}$ \\
\hline $10 \mathrm{c}$ & & $\begin{array}{l}\text { in the case of 3DPTs utilizing tissues or cells of animal origin, or their derivatives, as referred to in Regulation } \\
\text { (EU) No 722/2012 the particular requirements laid down in that Regulation shall apply. }\end{array}$ \\
\hline 11 & & $\begin{array}{c}\text { 3DPT shall meet labelling requirements clearly highlighting the methods used to verify and validate the safety } \\
\text { and performance of the respective 3DPT }\end{array}$ \\
\hline 12 & & Where applicable, 3DPTs must meet all SPRs stipulated in MDR, Annex 1. \\
\hline
\end{tabular}

To display verification and validation results in a transparent and comparable approach, the authors have defined a scoring system: The Safety and Performance Evidence Level (SP Evidence Level for 3DPTs) Scoring System (S.P.E.L.) for 3D implant manufacturing technologies. This S.P.E-L. scoring system is derived and based on the S.P.E.L. scoring system for surface functionalization technologies [14]. The scoring system (Table 6) defined in this publication does not assess the values and results of the verification and validation activities performed, but starts at a fundamental level: the scoring system does not assess the individual test results, but rather the "evidence level" of the underlying verification and validation strategy. Thus, it is possible to relate each result to the verification and validation strategy and better assess the overall evidence level.

With this scoring system, data of 3D printing technologies are transparently displayed, and test methods aligned to such an extent that the potential user - surgeon or POC operator - can compare different technologies with each other. This scoring system is the first attempt to establish a standardized and transparent test system for the quality of 3DPT products and is divided into four subsections: Design and development, manufacturing, mechanical testing, clinical applicability. In each subsection a maximum evidence level of $100 \%$ can be reached. Note: Every subsection (sections I-IV) only represents $25 \%$ of the overall evidence level (degree of fulfillment). The overall evidence level can reach a maximum of $100 \%$ and is calculated as follows: $[\mathrm{e} 1(0,25) *(\mathrm{XX} \%)$ $\left.+\mathrm{e} 2(0,25) *(X X \%)+\mathrm{e} 3(0,25) *(X X \%)+\mathrm{e} 4(0,25)^{*}(X X \%)\right]=X X \%$.

With this scoring system, the significance and applicability of verification and validation procedures can be determined that have been carried out to evaluate the marketability of a 3DPT. Thus an evaluation platform was created, which can be used systemindependently of country-specific regulations (EU:MDR / US:FDA / China:cFDA / Brazil:ANVISA, etc.), in order to make comparable and transparent statements regarding the significance of test results. Our current focus lies on polymer implant materials, but the principle can easily be adapted to all 3D printable materials. Of course, the future will show the applicability of the scoring system and adaptations might become necessary but what is essential is that the here suggested system is the first step towards a transparent evaluation of 3D printed medical devices. A quality seal - issued by a neutral authority, such as a certification authority or Notified Body, accredited for the evaluation of medical devices and quality management systems - could provide the necessary transparency. It shall indicate in combination (i) the 3D printing method according to Table 1 (ii), the risk profile / risk classification of the 3DPT according to Table 4, (iii) the material incorporated and (iv) the Safety and Performance Evidence Level and its degree of fulfillment for the respective 3DPT according to Table 6. 
Table 6: Safety and Performance Evidence Level (SP Evidence Level for 3DPTs).

\begin{tabular}{|c|c|c|c|c|c|}
\hline & & & Grading System & Impact Score & $\begin{array}{l}\text { Degree of Fulfill- } \\
\text { ment }\end{array}$ \\
\hline eI & \multicolumn{5}{|c|}{ Design and Development (only one answer possible. Max: 3 points $=100 \%$ ) } \\
\hline & \multirow{8}{*}{$\begin{array}{l}\text { Design and Devel- } \\
\text { opment }\end{array}$} & \multirow{2}{*}{ Verified and validated, certified acc. ISO 13485} & YES & 3 & \multirow{2}{*}{$100 \%$} \\
\hline & & & NO & 0 & \\
\hline & & \multirow{2}{*}{$\begin{array}{l}\text { Verified and validated, according to GMP } \\
\text { standard }\end{array}$} & YES & 2 & \multirow{2}{*}{$66 \%$} \\
\hline & & & NO & 0 & \\
\hline & & \multirow{2}{*}{ Verified and validated } & YES & 1 & \multirow{2}{*}{$33 \%$} \\
\hline & & & NO & 0 & \\
\hline & & \multirow{3}{*}{ No Validation } & YES & 0 & \multirow{2}{*}{$0 \%$} \\
\hline & & & NO & 0 & \\
\hline & & & \multicolumn{2}{|c|}{ Subtotal } & $100 \%(1 / 4)$ \\
\hline eII & \multicolumn{5}{|c|}{ Manufacturing Method (only one answer possible. Max: 4 points = $100 \%$ ) } \\
\hline & \multirow{10}{*}{$\begin{array}{l}\text { Manufacturing } \\
\text { Process }\end{array}$} & \multirow{2}{*}{$\begin{array}{l}\text { Manufacturing process (industrial scale) is } \\
\text { verified, validated and ISO } 13485 \text { certified. It } \\
\text { does not adversely effect mechanical properties } \\
\text { of the implant material during processing }\end{array}$} & YES & 4 & \multirow[b]{2}{*}{$100 \%$} \\
\hline & & & NO & 0 & \\
\hline & & \multirow{2}{*}{$\begin{array}{l}\text { Manufacturing process (industrial scale) is veri- } \\
\text { fied, and validated. It does not adversely effect } \\
\text { mechanical properties of the implant material } \\
\text { during processing }\end{array}$} & YES & 3 & \multirow[b]{2}{*}{$75 \%$} \\
\hline & & & NO & & \\
\hline & & \multirow{2}{*}{$\begin{array}{l}\text { Manufacturing process (industrial scale) is veri- } \\
\text { fied and validated, according to GMP standard }\end{array}$} & YES & 2 & \multirow[b]{2}{*}{$50 \%$} \\
\hline & & & NO & 0 & \\
\hline & & \multirow{2}{*}{ Patient matched concept verified and validated } & YES & 1 & \multirow{2}{*}{$25 \%$} \\
\hline & & & NO & 0 & \\
\hline & & \multirow{3}{*}{$\begin{array}{l}\text { Patient matched concept not verified and } \\
\text { validated }\end{array}$} & YES & 0 & \multirow{2}{*}{$0 \%$} \\
\hline & & & NO & 0 & \\
\hline & & & \multicolumn{2}{|c|}{ Subtotal } & $100 \%(1 / 4)$ \\
\hline eIII & \multicolumn{5}{|c|}{ Pre-clinical Testing: Abrasion and Delamination (only one answer possible. Max: 3 points $=100 \%$ ) } \\
\hline & \multirow{9}{*}{ Mechanical Testing } & \multirow{2}{*}{$\begin{array}{l}\text { Rationale \& verified and validated, performed } \\
\text { by an accredited laboratory }\end{array}$} & YES & 3 & \multirow[b]{2}{*}{$100 \%$} \\
\hline & & & NO & 0 & \\
\hline & & Dationole \& yorified and yolidated & YES & 2 & \multirow{2}{*}{$66 \%$} \\
\hline & & Ratıonale \& verıfıed and valıdated & NO & 0 & \\
\hline & & Pationolo & YES & 1 & $220 \%$ \\
\hline & & Kationdie & NO & 0 & $35 \%$ \\
\hline & & Other & YES & 0 & 000 \\
\hline & & Utner & NO & 0 & $0 \%$ \\
\hline & & None & & FAILED & \\
\hline & & & Subtc & & $100 \%(1 / 4)$ \\
\hline eIV & & Applicability (only one answer po & le. Max: 4 points & 0 \%) & \\
\hline
\end{tabular}


Academic Journal of Polymer science

\begin{tabular}{|c|c|c|c|c|}
\hline \multirow{10}{*}{$\begin{array}{l}\text { Limitation of clini- } \\
\text { cal applicability }\end{array}$} & \multirow{2}{*}{$\begin{array}{l}\text { Surgical technique, storage, packaging, cleaning, } \\
\text { and sterilization requirements of the implant } \\
\text { made with 3DPT are not affected by 3DPT }\end{array}$} & YES & 4 & \multirow{2}{*}{$100 \%$} \\
\hline & & NO & 0 & \\
\hline & \multirow{2}{*}{$\begin{array}{l}\text { Only storage conditions of the implant made } \\
\text { with 3DPT must be adapted to the require- } \\
\text { ments of 3DPT }\end{array}$} & YES & 3 & \multirow{2}{*}{$75 \%$} \\
\hline & & NO & 0 & \\
\hline & \multirow{2}{*}{$\begin{array}{l}\text { Storage, packaging, cleaning, and sterilization } \\
\text { conditions of the implant made with 3DPT } \\
\text { must be adapted to the requirements of 3DPT }\end{array}$} & YES & 2 & \multirow{2}{*}{$50 \%$} \\
\hline & & NO & 0 & \\
\hline & \multirow{2}{*}{$\begin{array}{l}\text { Surgical technique must be adapted to the } \\
\text { requirements of 3DPT }\end{array}$} & YES & 1 & \multirow{2}{*}{$25 \%$} \\
\hline & & NO & 0 & \\
\hline & \multirow{2}{*}{$\begin{array}{c}\text { 3DPT cannot be stored using standard storage } \\
\text { conditions guaranteeing a shelflife of }(>/=) 5 \\
\text { years }\end{array}$} & YES & 0 & \multirow{2}{*}{$0 \%$} \\
\hline & & NO & 0 & \\
\hline & & \multicolumn{2}{|c|}{ Subtotal } & $100 \%(1 / 4)$ \\
\hline
\end{tabular}

\section{Case Study}

To realize 3D printed implants for long-term use or invasive instruments for transient use in a POC setting, it was decided to use a material already approved for the purpose of transient use (Ketaspire® HC AM Filament MS NT1 filament, by Solvay). This is essential to ensure the biocompatibility of the material used in a POC setting and to avoid verifying its capability in a time-consuming way analogous to ISO 10993 standards. To manufacture implants in a POC setting, the different AM technologies were analyzed, for example, SLS and FFF. As in a POC setting, cleanliness not only of the product but also of the environment is vital, it was decided not to use powder-based SLS or EBM methods but FFF-AM as the manufacturing method of choice. According to the risk classification principles displayed in Table 4, the printing pathway can be defined - based on the choice of materials - as Class 1, low risk. According Table 6, it was further decided to use AM equipment that has been specially developed and made available to produce POC products (M-series printer, orion Medical AM / R1 KUMOVIS). The different manufacturing processes were analyzed, mechanically tested, and validated as far as possible in advance. Only processes that have been validated before guarantee consistent mechanical properties of the POC products: High-performance polymers like PEEK are semi-crystalline thermoplastics which are typically injection molded with nearly isotropic properties.

Typically, the FFF process produces anisotropic behavior compared to injection molding. This is mainly due to cooling down of the material after being deposited in an air-heated chamber. The filament is often not molten throughout the entire diameter, which results in some porous structures leading to weaker interlayer bonding. However, when Thermal Radiation Heating (TRH) is applied during the printing process, the layer fuse together resulting in uniform properties and nearly isotropic stress, strain, Young's Modulus and hardness throughout the part (Table 7). The TRH Technology (Orion AM) efficiently heats the filament and the print from all directions up to $300^{\circ} \mathrm{C}$. The thermal radiation is emitted at an emission spectrum similar to the absorbance spectrum of the material, further optimizing the energy transferred to the material and thus increasing the interlayer bonding and improving mechanical strength. Basically, TRH penetrates through the material, allowing the layers to truly fuse together. The effectiveness of TRH is depending on the right radiation spectrum, locations of radiation sources and nozzle diameter. The right combination leads to no visible layers, hence no porous structure and therefore to increased interlayer bonding.

Table 7: 0-Series - verification and validation setup.

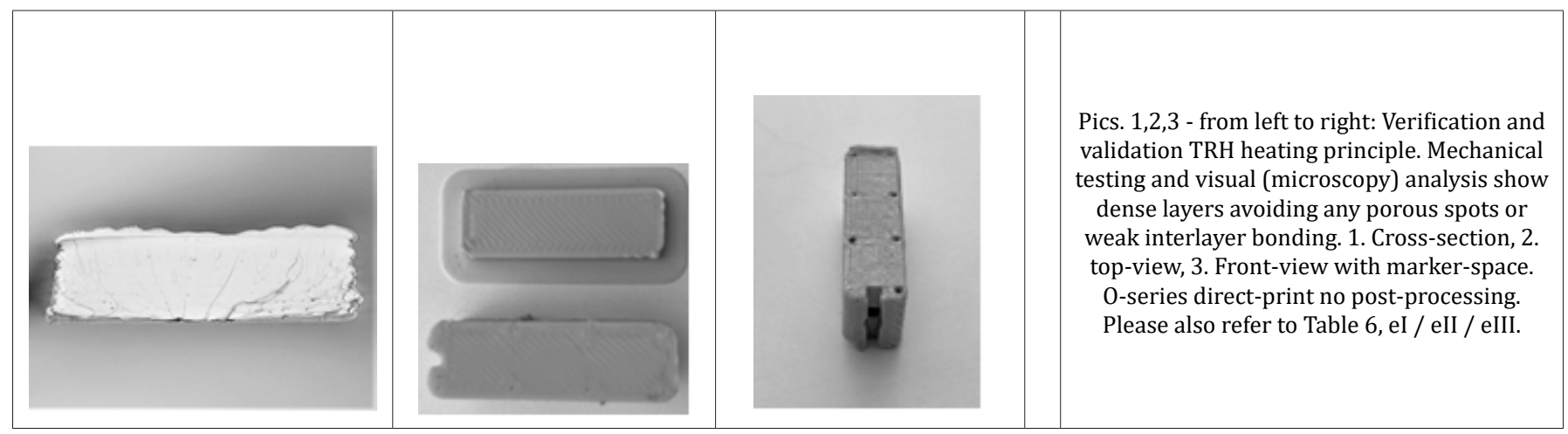


We calculate S.P.E.L. for 3DPTs according Table 6: $\left[e 1(0,25) *(66 \%)+e 2(0,25) *(75 \%)+e 3(0,25)^{*}(66 \%)+\right.$ e $4(0,25) *(100 \%)]=>76,75 \%$ S.P.E.L. at the time of evaluation. By repeating cerification and validation tests by accreditated testing labs and certifying the AM technology supplier a S.P.E.L. of $100 \%$ can be reached. Products that are used for orthopedic-surgical purposes often require osseointegrative surface properties. Therefore, it is usually essential to functionalize the surfaces of implants if they are made from polymers such as PEEK. Standard finishing technologies are coating processes in which the implant surfaces are coated with an osseointegrative material. With a growing need for coating technologies to functionalize the surface of polymeric medical devices, the medical industry saw enormous growth in coating applications onto medical devices. Various coating technologies, coating materials, and substances are available to date, spanning from plasma spray coating technologies to dip-coating techniques, from titanium or hydroxyapatite, all of which enhance cell attachment onto orthopedic implants. However, there are also various risks associated with the materials and methods mentioned above: amongst others, delamination, wear debris, abrasion, particle migration, infection, or corrosion. Analyzing the various surface modification technologies, it was decided to use a metal-free surface finishing: a mechanical stable surface functionalization method and patented, bio-chemically covalently bound surface functionalization process (MBT, stimOS $\mathrm{GmbH}$ ), Standards and guidelines followed during design and development of surface functionalization technology (SFT) are summarized in Table 8. To demonstrate the conformity of the SFT with regulatory requirements and to align SFT development with Medical Device Regulation (Regulation EU 2017/745) requirements, the S.P.E.L. approach was applied to prove MBT's safety and (clinical) performance in a worst-case setting, allowing the transfer of the results to the needs of the various application possibilities. With S.P.E.L, a a unique evaluation matrix has been developed and published in open access [14], to enable decisionmakers in the use of POC solutions to make a well-founded judgment about the safety and (clinical) performance of the POC technologies: As 3D printed parts manufactured in the medical and MedTech environment are intended to be used as (patientmatched) implants or (patient-specific) instruments, a catalog of safety and performance requirements mandatory for 3D printing technologies was developed, which is inspired by Regulation (EU) 2017/745, Annex I (Table 9).

Table 8: Standards and guidelines followed during design and development of SFT.

\begin{tabular}{|c|c|c|c|}
\hline Title & Description & Comment & $\begin{array}{l}\text { Applied [YES] } \\
{[\text { [NO] }}\end{array}$ \\
\hline ISO 13485 & $\begin{array}{l}\text { Standard for legal manufacturers of } \\
\text { medical devices }\end{array}$ & $\begin{array}{c}\text { Development of MBT was done according to ISO } 13485 \\
\text { requirements. }\end{array}$ & YES \\
\hline ISO 14971 & $\begin{array}{l}\text { Standard for risk management activ- } \\
\text { ities }\end{array}$ & $\begin{array}{c}\text { Development of MBT was done according to ISO } 14971 \\
\text { requirements. }\end{array}$ & YES \\
\hline ISO 10993 & Biocompatibility test requirements & $\begin{array}{c}\text { Development of MBT was done according to ISO } 10993 \\
\text { requirements. }\end{array}$ & YES \\
\hline $\begin{array}{l}\text { MDD Essential Require- } \\
\text { ment }\end{array}$ & $\begin{array}{c}\text { General requirements for medical } \\
\text { devices }\end{array}$ & MBT respects and fulfills MDD requirements. & YES \\
\hline $\begin{array}{l}\text { MDR General safety and } \\
\text { Performance Require- } \\
\text { ments }\end{array}$ & $\begin{array}{c}\text { General requirements for medical } \\
\text { devices }\end{array}$ & MBT respects and fulfills MDR requirements. & YES \\
\hline S.P.E.L. SFT & $\begin{array}{l}\text { Safety and Performance Evdence Level } \\
\text { for SFT }\end{array}$ & Voluntary quality anaylsis was applied. & YES \\
\hline $\begin{array}{l}\text { Good Laboratory Practice } \\
\text { (GLP) }\end{array}$ & $\begin{array}{l}\text { QM System for laboratory work, } \\
\text { including animal testing environment } \\
\text { and documentation }\end{array}$ & $\begin{array}{l}\text { Animal model was setup and carried out respecting GLP } \\
\text { standards. }\end{array}$ & YES \\
\hline $\begin{array}{l}\text { ASTM Mechanical Testing } \\
\text { D3359 }\end{array}$ & $\begin{array}{l}\text { Adhesion test method for surface } \\
\text { coating technologies }\end{array}$ & Mechanical testing included ASTM test methods. & YES \\
\hline
\end{tabular}

Table 9: Design and development efforts transferred into industrial application, ready for CE marking.

\begin{tabular}{|c|c|c|}
\hline Pic.4 & Pic. 5 & $\begin{array}{l}\text { Pic. 4: stimOS spineFuse MBT implant } \\
\text { family. MBT finished surface for early } \\
\text { osseointegration and better anchorage. } \\
\text { spineFuse implants are subject to clinical } \\
\text { evaluation according MDR (EU) } 2017 / 745 \text {. } \\
\text { Pic. } 5 \text { : stimOS spacer instruments for } \\
\text { spineFuse MBT implants: Series 1, direct } \\
\text { print - no surface finishing or post- } \\
\text { processing after additive manufacturing. } \\
\text { stimOS spacer instruments are made from } \\
\text { PPSU using patented Thermal Radiation } \\
\text { Heating (orion AM). spineFuse } \\
\text { instruments are subject to CE marking. }\end{array}$ \\
\hline
\end{tabular}


The mode of operations of the functionalization method, its safety and clinical performance, was verified and validated beforehand by means of mechanical testings, comparative cell tests in vitro and in vivo in a comparative animal model: The MBT procedure was developed using ISO 13485 certified processes and GLP standards. MBT was also developed considering the safety and (clinical) performance requirements as prescribed by the Medical Device Regulation (EU) 2017/745 for implants. For this purpose, the requirements from Annex I of the Medical Device Regulation (Regulation EU 2017/745) were adapted to the requirements for coating technologies. Mechanical testing followed a precise defined test and verification matrix. Each test followed its own rationale and test setup. Where possible, standard test methods and accredited facilities have been used. As MBT is an entirely innovative SFT, general standard test methods for this technology are not established but have been defined, described, executed, and evaluated. During the design and development and during design transfer, comparative cell tests have been performed. Relevant cell lines have been used to prove the unique characteristics of MBT compared to standard and golden standard materials: Titanium coated PEEK, Ha-enhanced PEEK, and pure PEEK. A comparative animal model has been performed according to GLP standards by Vetsuisse Zurich. The study protocol was approved by the veterinarians of the Kanton ZH (University of Zurich, Vetsuisse, study protocol number: ZH132/18, study title: MBT - a new covalent binding molecule for enhancing osseointegration). A comparative split mouth study setup was used. Screw-design test dowels have been implanted in dense bone of sheep and analyzed via histology measurements. For the applicability of MBT, it can be stated that the SFT does not influence the clinical applicability of the connected medical device: Surgical technique, storage, packaging, cleaning, and sterilization requirements of the implant incorporating MBT are not affected by SFT. Only if POC products are modularly composed of pre-verified and validated building blocks, as described above, the safe use and clinical benefit can be guaranteed in general, without subjecting the POC products individually to a test procedure.

\section{Discussion}

Regulation (EU) 2017/745 defines different responsibilities and obligations for economic operators in the medical technology environment. For the manufacturer, the most comprehensive requirements apply to design and development, production, marketing, and post-market surveillance. However, distributors are also held accountable. The user - for example, the surgeon himself is not explicitly covered by the regulation with duties and responsibilities. He is often subject to special national obligations, e.g., in Germany, the obligations according to the Medical Devices Operator Ordinance (MPBetreibV). However, it is assumed that he uses a product within its intended purpose. Of course, within the scope of his or her freedom of therapy and under certain circumstances, a physician can also use a product outside its intended purpose.
This clear division of roles of the economic actors - legal manufacturer - distributor - user - blurs with the requirement of manufacturing medical devices as point-of-care products. If a user, for example, a physician, manufactures, uses, and charges for medical devices, obligations of the legal manufacturer and distributor are also transferred to him. In particular, the obligations as described in Regulation (EU) 2017/745 in Articles 13, 14, and 15 in Chapter III and in Annex II should apply. For example, the requirement for a quality management system, the maintenance of a product file, the technical documentation, and the obligation to observe the market and to guarantee traceability and to have a vigilance concept implemented. However, there are also certain simplifications for medical devices whose manufacture and use takes place "only within" a healthcare institution, as the Regulation (EU) 2017/745 describes in Art. 5 Sec.5. This does not exempt healthcare institutions from extensive requirements for the use, documentation, disclosure, evaluation, and monitoring of such in-house manufacture. This exemption will also not apply to every type of product $[10,15]$.

\section{Conclusion}

Many advocates of visionary POC solutions are often unaware of these legal and regulatory frameworks that define the responsibilities of manufacturers of POC products. It can also be assumed that operators of point of care institutions, such as the administrative management of hospitals or the operators of outpatient clinics, do not want to face these responsibilities and obligations. The authors therefore propose to implement POC solutions as POC service, supplied by certified medical technology service providers, at the location of hospitals and outpatient clinics.

\section{References}

1. Oliveira TT, Reis AC (2019) Fabrication of dental implants by the additive manufacturing method: A systematic review. The Journal of prosthetic dentistry 122(3): 270-274.

2. Turner BN, Strong R, Gold SA (2014) A review of melt extrusion additive manufacturing processes: I. Process design and modeling. Rapid Prototyping Journal 20(3): 192-204.

3. Wang Y, Müller WD, Rumjahn A, Schwitalla A (2020) Parameters influencing the outcome of additive manufacturing of tiny medical devices based on PEEK. Materials 13(2): 466.

4. Yang C, Tian X, Li D, Cao Y, Zhao F, et al. (2017) Influence of thermal processing conditions in 3D printing on the crystallinity and mechanical properties of PEEK material. Journal of Materials Processing Technology 248: 1-7.

5. Han X, Yang D, Yang C, Spintzyk S, Scheideler L, et al. (2019) Carbon fiber reinforced PEEK composites based on 3D-printing technology for orthopedic and dental applications. Journal of clinical medicine $8(2)$ : 240 .

6. Basgul C, Yu T, MacDonald DW, Siskey R, Marcolongo M, et al. (2018) Structure-property relationships for 3D-printed PEEK intervertebral lumbar cages produced using fused filament fabrication. Journal of materials research 33(14): 2040-2051. 
7. Han X, Sharma N, Xu Z, Scheideler L, Geis GJ, et al. (2019) An in vitro study of osteoblast response on fused-filament fabrication 3D printed PEEK for dental and cranio-maxillofacial implants. Journal of clinical medicine 8(6): 771 .

8. Mironov V, Kasyanov V, Drake C, Markwald RR (2008) Organ printing: promises and challenges. Future Medicine 3(1): 93-103.

9. Murphy SV, Atala A (2014) 3D bioprinting of tissues and organs. Nature biotechnology 32(8): 773-785.

10. Schaffarczyk D, Koslowski C, Schwitalla A, Scholl D, Hämmerle I, et al. (2021) Applying S.P.E.L. standard to patient matched devices: The need for a transparent regulatory matrix to qualify new manufacturing methods and technologies.
11. Medical Device Regulation (EU) 2017/745, Annex I In Chapter I, 3.

12. Medical Device Regulation (EU) 2017/745, Annex I. In Chapter I, 4 (a).

13. Medical Device Regulation (EU) 2017/745, Annex I In Chapter II, 10.1 (d), (f), (g).

14. Schaffarczyk D, Knaus J, Peeters G, Scholl D, Schwitalla A, et al. (2020) Polyetheretherketone implant surface functionalization technologies and the need for a transparent quality evaluation system. Polymer International 70(8): 1002-1015.

15. Oeben M (2020) Die Eigenherstellung von Medizinprodukten nach der MDR-Voraussetzungen und Grenzen der Herstellung. innerhalb einer Gesundheitseinrichtung, p. 6.

\section{Your next submission with Juniper Publishers will reach you the below assets}

- Quality Editorial service

- Swift Peer Review

- Reprints availability

- E-prints Service

- Manuscript Podcast for convenient understanding

- Global attainment for your research

- Manuscript accessibility in different formats ( Pdf, E-pub, Full Text, Audio)

- Unceasing customer service

Track the below URL for one-step submission https://juniperpublishers.com/online-submission.php 